TERRORIZING WOMEN 

ROSA-LINDA FREGOSO

AND CYNTHIA BEJARANO, EDITORS

\section{TERRORIZING WOMEN}

\section{Feminicide in the Américas}

WITH A PREFACE BY MARCELA LAGARDE Y DE LOS RÍOS 
(C) 20Io Duke University Press All rights reserved

Printed in the United States of America on acid-free paper $\infty$ Typeset in Carter and Cone Galliard with Gill Sans display by Keystone Typesetting, Inc. Library of Congress Cataloging-inPublication Data appear on the last printed page of this book. 
Is

IN MEMORY OF

THE WOMEN AND GIRLS

WHO HAVE BEEN MURDERED

AND DISAPPEARED. 
